\title{
Optimasi Perencanaan Produksi Kue Dan Bakery di Home Industry "SELARAS CAKE" Menggunakan Model Goal Programming
}

\author{
Nusaibah Al Istiqomah dan Dwi Lestari \\ Program Studi Matematika, FMIPA Universitas Negeri Yogyakarta, Jl. Colombo No.1, Caturtunggal, \\ Depok, Yogyakarta, Indonesia
}

Korespondensi; Nusaibah Al Istiqomah,Email: nusaibah1603@gmail.com; Dwi Lestari,Email: dwilestari@uny.ac.id

\begin{abstract}
Abstrak
Penelitian ini bertujuan untuk: mengetahui model penyelesaian masalah perencanaan produksi dengan model goal programming tanpa prioritas tujuan dan model goal programming dengan prioritas tujuan, menentukan ramalan permintaan aneka kue dan bakery serta menentukan mana yang lebih optimal antara kedua model dalam menentukan jumlah produksi. Penelitian ini dilakukan pada produk aneka kue dan bakery seperti muffin pisang, brownies, bolu rol, greenis, pizza bakery dan coklat bakery. Dengan mengkaji dari beberapa literatur, permasalahan ini dapat diselesaikan dengan menggunakan model goal programming tanpa prioritas tujuan dan model goal programminng dengan prioritas tujuan. Berdasarkan hasil penelitian, rencana produksi yang dihasilkan dari kedua model sama, yaitu jumlah produksi muffin pisang sebanyak 31586 unit, greenis sebanyak 31839 unit, bolu rol sebanyak 31839 unit, brownies sebanyak 60645 unit, coklat bakery sebanyak 16425 unit, dan pizza bakery sebanyak 164245 unit. Sementara itu, dari model goal programming tanpa prioritas tujuan diperoleh pendapatan perusahaan sebesar $R p$ 426.034.500,00 dengan biaya produksi sebesar $R p$ 147.021.000,00, sedangkan keuntungan dari model goal programming dengan prioritas tujuan sebesar $\mathrm{Rp}$ 376.759.500,00 dan biaya produksi sebesar $\mathrm{Rp}$ 131.006.600,00. Ini berarti, jika keuntungan diasumsikan dengan pendapatan dikurangi biaya produksi, maka untuk keuntungan yang lebih besar, perusahaan disarankan menggunkan model goal programming tanpa prioritas tujuan karena menghasilkan hasil pengurangan yang lebih besar.
\end{abstract}

Kata Kunci: Perencanaan Produksi; Goal Programming; Prioritas

\begin{abstract}
This study aimed to: know the model of the production planning problem solving goal programming model without the priority objectives and goal programming model of the priority goals, determine the demand forecast cakes and bakery as well as to determine which is optimal between the two models in determining the amount of production. This research was conducted in bakery products such as cakes and banana muffins, brownies, sponge rollers, greenis, bakery and chocolate pizza bakery. By reviewing of some of the literature, this problem can be solved by using a goal programming models and models without priority objectives programminng goal with the priority goal. Based on the research, production plans generated from both models is identical, ie the amount of production of banana muffins as many as 31586 units, greenis as many as 31839 units, sponge rollers as many as 31839 units, brownies as many as 60645 units, chocolate bakery as many as 16425 units, and pizza bakery as many as 164245 units, Meanwhile, on the model of goal programming without priority objectives the company obtained revenue of $R p 426,034,500.00$ with a production cost of US $\$ 147,021,000.00$, while the advantages of goal programming models with a priority goal of $R p 376,759,500.00$ and production costs $R p 131,006,600.00$. This means, if the profit is assumed to revenue minus production costs, then for a greater profit, the company suggested using the model of goal programming without priority objectives for yield greater reductions.
\end{abstract}

Keywords: Production Planning; Goal Programming; Priority

\section{Pendahuluan}

Memasuki era globalisasi seperti sekarang ini, dunia usaha dihadapkan dengan persaingan yang sangat ketat. Untuk itu, sebuah perusahaan harus memiliki strategi yang tepat dalam menghadapi persaingan 
yang semakin kompetitif dan bisa bertahan menghadapi persaingan tersebut. Perusahaan harus bisa melakukan antisipasi terhadap permintaan pasar yang terus meningkat sehingga dapat memuaskan konsumen dan mampu bertahan dalam persaingan usaha. Bentuk antisipasi ini dapat bermacammacam, salah satunya adalah dengan membuat perencanan produksi. Perencanaan produksi (production planning) adalah perencanaan tentang produk apa dan berapa yang akan diproduksi oleh perusahaan dalam satu periode yang akan datang. Dalam perencanaan produksi, perusahaan tidak hanya memperhatikan permintaan konsumen tetapi perusahaan juga perlu memperhatikan tiga elemen, yaitu konsumen, produk, dan proses manufaktur.

Dalam penelitian ini, penulis melakukan penelitian di salah satu home industry yang bergerak dibidang makanan. Penulis juga membatasi penelitian pada enam produk yaitu, muffin pisang, greenis, bolu rol, brownie, coklat bakery dan pizza bakery. Permasalahan yang diteliti adalah bagaimana menentukan jumlah produksi yang optimal berdasarkan jumlah permintaan konsumen, memaksimalkan pendapatan, meminimalkan biaya produksi dan memaksimalkan jam kerja mesin. Secara matematis, permasalahan ini termasuk dalam masalah dengan tujuan lebih dari satu atau pemrograman linear tujuan ganda. Salah satu model yang digunakan dalam penelitian ini adalah model goal programming.

Goal Programming merupakan suatu perluasan dari linear programming yang mempunyai multitujuan, sehingga seluruh asumsi, notasi, formulasi model matematis, prosedur perumusan model dan penyelesaiannya tidak jauh berbeda. Perbedaannya terletak pada variabel deviasional yang akan muncul di fungsi tujuan dan fungsi-fungsi kendala. Variabel deviasional berfungsi untuk menunjukkan penyimpangan-penyimpangan atau deviasi yang akan terjadi pada nilai ruas kiri suatu persamaan kendala terhadap nilai ruas kanannya (Siswanto, 2007). Goal programming dapat meningkatkan fleksibilitas linear programming dengan memasukkan berbagai tujuan, disamping tetap dapat menghasilkan suatu solusi optimal dalam kaitannya dengan prioritas tujuan.

Penelitian mengenai aplikasi model goal programming untuk penyelesaian masalah optimisasi sudah banyak dilakukan. Mansoureh Farzam dalam penelitiannya yang berjudul proposing an aggregate production planning model by goal programming approach, a case study pada tahun 2014 memperoleh hasil bahwa model goal programming dapat mewakili solusi yang lebih tepat dibanding dengan model satu objektif, Nasruddin Hassan dkk dalam penelitiannya yang berjudul a goal programming model for bakery production pada tahun 2013 mendapati hasil bahwa model goal programming berguna bagi usaha keil dan menengah (UKM) dalam memaksimalkan jumlah produksi dan menghitung keuntungan produksi, Muchlison Anis dalam penelitiannya yang berjudul optimasi perencanaan produksi dengan metodel goal programming tahun 2007 menghasilkan bahwa model goal programming sangat potensial jika digunakan untuk menentukan perencanaan produksi yang merupakan masalah kompleks karena mengandung sasaran yang berbeda dan kompleks.

Berdasarkan uraian di atas penelitian ini bertujuan untuk menyelesaikan masalah perencanaan produksi aneka kue dan bakery dengan menggunakan model goal programming tanpa prioritas tujuan dan model goal programming dengan prioritas tujuan untuk optimisasi produk pada home industry 'Selaras Cake'. Adapun yang menjadi fungsi tujuan dalam penelitian ini adalah jumlah produksi untuk memenuhi permintaan konsumen, pendapatan penjualan, biaya produksi dan jam kerja mesin. Selanjutnya, penyelesaian model goal programming tanpa prioritas tujuandan model goal programming dengan prioritas tujuan akan dibantu menggunakan sofware LINGO.

\section{Metode Penelitian}

Penelitian ini termasuk jenis penelitian bersifat deskriptif. Pengumpulan data dilakukan dengan cara wawancara langsung. Dalam penelitian ini data diambil di Home Industry 'Selaras Cake' pada periode Agustus 2015 - Mei 2016. Jenis data pada penelitian ini yaitu data primer dan data sekunder. Data primer berupa wawancara (interview) langsung. Data sekunder berupa data produk sebagai berikut: bahan baku, penjualan, biaya produksi, harga produk, dan jumlah jam kerja mesin.

Proses penyelesaian masalah dalam suatu penelitian dikenal dengan nama pemodelan matematika. Dalam pemodelan matematika dipelajari terdapat tahap-tahap yang sistematis. Karena kondisi real yang kompleks maka beberapa asumsi perlu dibangun sehingga model matematis yang terbentuk dapat diselesaikan dengan lebih mudah. Asumsi-asumsi yang digunakan dalam penelitian ini adalah: 
1. Bahan baku selalu mencukupi untuk proses produksi.

2. Harga bahan baku tidak berubah.

3. Jumlah produk yang diproduksi sama dengan jumlah produk yang di jual.

4. Tidak ada pengembalian produk dari konsumen.

5. Perusahaan tidak menetapkan nominal keuntungan yang ingin dicapai.

6. Jumlah pegawai tetap, sehingga tidak mempengaruhi pengambilan keputusan.

Adapun langkah-langkah penyelesaian dalam penelitian ini adalah menentukan notasi untuk jenisjenis produk yang akan diteliti dengan variabel $X_{i}$, dengan $i=1,2,3,4,5,6$ sesuai dengan banyaknya produk yang diteliti, kemudian meformulasikan data tentang jenis-jenis produk tersebut ke dalam model goal programming.

\section{Pembentukan Model Matematika Perencanaan Produksi Dengan Goal programming Tanpa Prioritas Sasaran}

\section{Formulasi Fungsi Tujuan}

Dalam penelitian ini formulasi fungsi tujuan ditetapkan dengan menentukan sasaran teknis dan finansial yang disesuaikan dengan keinginan perusahaan, yaitu:

1. Memaksimalkan volume produksi untuk memenuhi permintaan

2. Memaksimalkan pendapatan penjualan

3. Meminimalkan biaya produksi

4. Memaksimalkan jam kerja mesin

Dari fungsi tujuan tersebut, terdapat variabel simpangan yang harus diminimumkan. Sehingga fungsi tujuan model goal programming pada permasalahan ini dapat diformulasikan sebagai berikut:

$$
\text { Meminimumkan } Z=\sum_{i=1}^{m}\left(d_{i}^{+}+d_{i}^{-}\right) \text {, untuk } i=1,2, \ldots, m \text { tujuan. }
$$

\section{Formulasi Fungsi Kendala}

Tujuan atau sasaran yang ingin dicapai dalam penelitian ini meliputi:

1. Sasaran memaksimalkan volume produksi untuk memenuhi permintaan

Dalam penelitian ini, jumlah permintaan konsumen akan diprediksikan dengan menggunakan data penjualan yang sudah ada. Data yang digunakan adalah data penjualan selama 10 bulan terhitung dari bulan Agustus (2015) sampai bulan Mei (2016). Data tersebut dapat dilihat di Tabel 2.

Untuk memprediksi banyaknya produk yang diproduksi pada periode selanjutnya dilakukan perhitungan peramalan. Perhitungan peramalan ini menggunakan software minitab dengan model moving average (MA), model single exponential smoothing (SES) dan model double exponential smoothing (DES). Hasil peramalan ketiga model tersebut dapat dilihat pada Tabel 2.

Dari hasil peramalan tersebut, peramalan menggunakan model single exponential smoothing memiliki hasil dengan error paling kecil sehingga data yang dipakai adalah data hasil peramalan menggunakan model single exponential smoothing dengan pembulatan keatas. Sehingga hasil peramalan untuk periode salanjutnya adalah muffin pisang sebanyak 31586 unit, greenis sebanyak 31839 unit, bolu rol sebanyak 31839 unit brownies sebanyak 60645 unit coklat bakery sebanyak 16425 unit dan pizza bakery sebanyak 16425 unit.

2. Sasaran memaksimalkan pendapatan penjualan Harga masing-masing produk dapat dilihat pada tabel berikut:

Tabel 1 Tabel Harga Produk.

\begin{tabular}{lllllll}
\hline No & $\mathbf{1}$ & $\mathbf{2}$ & $\mathbf{3}$ & $\mathbf{4}$ & $\mathbf{5}$ & $\mathbf{6}$ \\
\hline Jenis Produk & Muffin Pisang & Greenis & Bolu Rol & Brownies & Coklat Bakery & Pizza Bakery \\
Harga Jual (per Satuan) & Rp 3.000,- & Rp 2.000,- & Rp 1.500,- & Rp 2.000,- & Rp 3.000,- & Rp 3.000,- \\
\hline
\end{tabular}


3. Sasaran meminimalkan biaya produksi

Biaya produksi (output cost) merupakan biaya untuk melakukan proses produksi yang terdiri dari bahan bahan baku, biaya tenaga kerja langsung, dan biaya tak langsung (overhead). Perhitungan dari ketiga biaya tersebut erdapat pada Tabel 4.

4. Sasaran memaksimalkan jam kerja mesin

Pengoptimalan jam kerja mesin bertujuan untuk memenuhi jumlah permintaan konsumen akan produk. Jam kerja mesin dapat dilihat pada Tabel 5.

\section{Model Matematika}

Penelitian ini menggunakan model goal programming dengan variabel dan parameter yang digunakan dalam perumusan model adalah sebagai berikut:

$X_{i}$ : banyaknya produk ke- $i$.

$i \quad$ : jenis produk yang dihasilkan, $i=1,2,3,4,5,6$

$P_{i}$ : tingkat permintaan akan jenis produk ke- $i$

$d_{i}^{-}$: nilai penyimpangan di bawah $P_{i}$

$d_{i}^{+}$: nilai penyimpangan di atas $P_{i}$

$F_{1}$ : pendapatan penjualan produk

$F_{2}$ : biaya produksi yang dikeluarkan perusahaan

$H_{i}$ : harga jual per unit produk $i$

Tabel 2 Tabel Penjualan Produk.

\begin{tabular}{lcccccc}
\hline Bulan & $\begin{array}{c}\text { Muffin } \\
\text { Pisang (X1) }\end{array}$ & Greenis (X2) & $\begin{array}{c}\text { Bolu Rol } \\
(\mathbf{X})\end{array}$ & $\begin{array}{c}\text { Brownies } \\
(\mathbf{X})\end{array}$ & $\begin{array}{c}\text { Coklat } \\
\text { Bakery (X5) }\end{array}$ & $\begin{array}{c}\text { Pizza Bakery } \\
\text { (X6) }\end{array}$ \\
\hline Agustus & 3125 & 3150 & 3150 & 6000 & 1625 & 1625 \\
September & 3125 & 3150 & 3150 & 6000 & 1625 & 1625 \\
Oktober & 3250 & 3276 & 3276 & 6240 & 1690 & 1690 \\
November & 3125 & 3150 & 3150 & 6000 & 1625 & 1625 \\
Desember & 3125 & 3150 & 3150 & 6000 & 1625 & 1625 \\
Januari & 3125 & 3150 & 3150 & 6000 & 1625 & 1625 \\
Februari & 3000 & 3024 & 3024 & 5760 & 1560 & 1560 \\
Maret & 3250 & 3276 & 3276 & 6240 & 1690 & 1690 \\
April & 3250 & 3276 & 3276 & 6240 & 1690 & 1690 \\
Mei & 3125 & 3150 & 3150 & 6000 & 1625 & 1625 \\
\hline Total & 31500 & 31752 & 31752 & 60480 & 16380 & 16380 \\
\hline
\end{tabular}

Tabel 3 Tabel Hasil Peramalan Penjualan.

\begin{tabular}{lllllll}
\hline & $\begin{array}{l}\text { Muffin Pisang } \\
(\mathbf{X} 1)\end{array}$ & $\begin{array}{l}\text { Greenis } \\
(\mathbf{X})\end{array}$ & $\begin{array}{l}\text { Bolu Rol } \\
(\mathbf{X})\end{array}$ & $\begin{array}{l}\text { Brownies } \\
(\mathbf{X})\end{array}$ & $\begin{array}{l}\text { Coklat Bakery } \\
(\mathbf{X})\end{array}$ & $\begin{array}{l}\text { Pizza Bakery } \\
(\mathbf{X})\end{array}$ \\
\hline MA & 32083,3 & 32340 & 32340 & 61600 & 16683,3 & 16683,3 \\
SES & 31585,5 & 31838,2 & 31838,2 & 60644,5 & 16424,5 & 16424,5 \\
DES & 32230 & 32487,8 & 32487,8 & 61881,6 & 16759,6 & 16759,6 \\
\hline
\end{tabular}

$B_{i}$ : biaya produksi per unit produk $i$

$W_{i j}$ : waktu proses per unit produk $i$ di mesin $j$

$E$ : kapasitas jam kerja reguler mesin $j$ 


\section{Perumusan Fungsi Tujuan}

Meminimumkan:

$$
\begin{aligned}
Z= & \left(\begin{array}{c}
\left(d_{1}^{-}+d_{1}^{+}\right)+\left(d_{2}^{-}+d_{2}^{+}\right)+\left(d_{3}^{-}+d_{3}^{+}\right) \\
+\left(d_{4}^{-}+d_{4}^{+}\right)+\left(d_{5}^{-}+d_{5}^{+}\right)+\left(d_{6}^{-}+d_{6}^{+}\right)
\end{array}\right) \\
& +\left(d_{7}^{-}+d_{7}^{+}\right)+\left(d_{8}^{-}+d_{8}^{+}\right)+\left(d_{9}^{-}+d_{9}^{+}\right)
\end{aligned}
$$

\section{Perumusan Fungsi Kendala}

1. Kendala sasaran memaksimalkan jumlah produksi untuk memenuhi jumlah permintaan.

Dengan:

$X_{i}=$ banyaknya produk ke- $i$

$P_{i}=$ tingkat permintaan terhadap produk $i$

$d_{i}^{+}=$nilai penyimpangan di atas $P_{i}$

$$
\begin{gathered}
X_{i}-d_{i}^{+}=P_{i} \\
X_{1}-d_{1}^{+}=31586 \\
X_{2}-d_{2}^{+}=31839 X_{3}-d_{3}^{+}=31839 \\
X_{4}-d_{4}^{+}=60645 \\
X_{5}-d_{5}^{+}=16425 \\
X_{6}-d_{6}^{+}=16425
\end{gathered}
$$

\begin{tabular}{|c|c|c|c|c|c|}
\hline No & Jenis Produk & $\begin{array}{l}\text { Biaya Bahan Baku } \\
\text { (per Satuan) }\end{array}$ & $\begin{array}{l}\text { Biaya Tenaga Kerja } \\
\text { Langsung (per Satuan) }\end{array}$ & $\begin{array}{l}\text { Biaya Overhead } \\
\text { (per Satuan) }\end{array}$ & $\begin{array}{l}\text { Total Biaya } \\
\text { Produksi }\end{array}$ \\
\hline 1 & MuffinPisang & Rp700,00 & Rp150,00 & Rp75,00 & Rp925,00 \\
\hline 2 & Greenis & Rp650,00 & Rp75,00 & Rp75,00 & Rp800,00 \\
\hline 3 & Bolu Rol & Rp300,00 & Rp150,00 & Rp75,00 & Rp525,00 \\
\hline 4 & Brownies & Rp650,00 & Rp75,00 & Rp75,00 & Rp800,00 \\
\hline 5 & Coklat Bakery & Rp450,00 & Rp150,00 & Rp75,00 & Rp675,00 \\
\hline 6 & Pizza Bakery & Rp750,00 & Rp150,00 & Rp75,00 & Rp975,00 \\
\hline
\end{tabular}

Tabel 4 Tabel Biaya Produksi.

Tabel 5 Tabel Jam Kerja Reguler Mesin.

\begin{tabular}{clccc}
\hline No & Nama Mesin & Jumlah & $\begin{array}{c}\text { Jam Kerja Efektif } \\
\text { per-10 Bulan (Menit) }\end{array}$ & $\begin{array}{c}\text { Kapasitas Jam Kerja Efektif } \\
\text { per-10 Bulan (Menit) }\end{array}$ \\
\hline 1 & Mixer & 1 & 75600 & 75600 \\
2 & Oven & 1 & 75600 & 75600 \\
3 & Kompor & 6 & 75600 & 453600 \\
\hline \multicolumn{7}{c}{ Total } \\
\hline
\end{tabular}

Perusahaan ingin memenuhi setiap permintaan akan produk, maka fungsi tujuan menjadi meminimalkan angka penyimpangan positif $\left(d_{i}^{+}\right)$yang dapat ditunjukkan sebagai berikut:

$$
\operatorname{Min} Z=d_{1}^{+}+d_{2}^{+}+d_{3}^{+}+d_{4}^{+}+d_{5}^{+}+d_{6}^{+}
$$

2. Kendala sasaran memaksimalkan pendapatan penjualan

Dengan:

$H_{i}=$ harga jual per unit produk $i$

$X_{i}=$ jumlah produk $i$ yang diproduksi

$m$ = banyaknya jenis produk 
Fungsi tujuannya menjadi:

$$
3000 X_{1}+2000 X_{2}+1500 X_{3}+2000 X_{4}+3000 X_{5}+3000 X_{6}+d_{7}^{-}=F_{1}
$$

3. Kendala sasaran meminimalkan biaya produksi

Dengan:

$B_{i}=$ biaya produksi per unit produk $i$

Fungsi tujuannya sebagai berikut:

$$
925 X_{1}+800 X_{2}+525 X_{3}+800 X_{4}+675 X_{5}+975 X_{6}+d_{8}^{-}=F_{2}
$$

4. Kendala sasaran memaksimalkan jam kerja mesin

Dimana:

$W_{i}=$ waktu proses per unit produk $i$

$J E=$ kapasitas jam kerja reguler mesin

$d_{i}^{-}=$nilai penyimpangan di bawah $J R$

$d_{i}^{+}=$nilai penyimpangan di atas $J R$

$$
\begin{gathered}
\sum_{i=1}^{m} W_{i} X_{i}+d_{9}^{-}-d_{9}^{+}=J E \\
120 X_{1}+60 X_{2}+120 X_{3}+60 X_{4}+120 X_{5}+120 X_{6}+d_{9}^{-}-d_{9}^{+}=604.800
\end{gathered}
$$

\section{Pembentukan Model Matematika Perencanaan Produksi Dengan Goal Programming Dengan Prioritas Sasaran}

\section{Penetapan Prioritas Sasaran}

Pada penelitian ini, urutan prioritas tujuan dan pemberian bobot diperoleh dengan meminta penetapan urutan prioritas dari pengambil keputusan di perusahaan tersebut. Berikut ini penetapan dan pemberian bobot pada setiap prioritas sasaran yang ingin dicapai.

Tabel 6 Tabel Urutan Prioritas.

\begin{tabular}{lcc}
\hline Sasaran & Prioritas & Bobot \\
\hline - Memenuhi Jumlah Permintaan Produsi & 1 & 0.4 \\
- Memaksimalkan Pendapatan & 2 & 0.32 \\
- Meminimalkan Biaya Produksi & 3 & 0.23 \\
- Memaksimalkan Jam Kerja & 4 & 0.05 \\
\hline
\end{tabular}

Dengan mengasumsikan M1 sebagai sasaran dengan prioritas pertama, M2 sebagai sasaran dengan prioritas kedua, M3 sebagai sasaran dengan prioritas ketiga, dan M4 sebagai sasaran dengan prioritas keempat. Maka model fungsi tujuan dengan pemberian prioritas di dalamnya adalah:

Meminimumkan:

$$
Z=\sum_{i=1}^{9} M_{K}\left(\boldsymbol{d}_{i}^{+}+\boldsymbol{d}_{\boldsymbol{i}}^{-}\right)
$$

dimana untuk $i=1,2, \ldots, 9$ dan $K=1,2, \ldots, 6$. 


\section{Model Matematika}

Perbedaan pemodelan ini dengan pemodelan sebelumnya hanya terletak pada fungsi tujuan dengan kendala yang masih sama. Sehingga fungsi tujuan dengan prioritas berubah menjadi sebagai berikut:

Meminimumkan:

$$
Z=M 1\left(d_{1}^{+}+d_{2}^{+}+d_{3}^{+}+d_{4}^{+}+d_{5}^{+}+d_{6}^{+}\right)+M 2\left(d_{7}^{+}\right)+M 3\left(d_{8}^{+}\right)+M 4\left(d_{9}^{-}+d_{9}^{+}\right)
$$

Dengan kendala

$X_{1}-d_{1}^{+}=31586$

$X_{2}-d_{2}^{+}=31839$

$X_{3}-d_{3}^{+}=31839$

$X_{4}-d_{4}^{+}=60645$

$X_{5}-d_{5}^{+}=16425$

$X_{6}-d_{6}^{+}=16425$

$$
\begin{gathered}
3000 X_{1}+2000 X_{2}+1500 X_{3}+2000 X_{4}+3000 X_{5}+3000 X_{6}+d_{7}^{-}=F 1 \\
925 X_{1}+800 X_{2}+525 X_{3}+800 X_{4}+675 X_{5}+975 X_{6}+d_{8}^{-}=F 2 \\
120 X_{1}+60 X_{2}+120 X_{3}+60 X_{4}+120 X_{5}+120 X_{6}+d_{9}^{-}-d_{9}^{+}=604800
\end{gathered}
$$

\section{Hasil Penelitian dan Pembahasan}

Penyelesaian permasalahan yang telah diformulasikan dalam bentuk persamaan ini dilakukan dengan bantuan program komputer LINGO 14.0. Dalam penelitian ini peneliti menggunakan program LINGO untuk mencari informasi yang dibutuhkan antara lain:

1. Informasi solusi penyelesaian optimal (nilai fungsi tujuan, nilai variabel keputusan, nilai variabel devisional, nilai reduced cost) dan nilai-nilai slack, surplus serta dual price.

2. Informasi mengenai analisis sensitivitas terhadap nilai ruas kanan model persamaan.

\section{Penyelesaian Optimal Goal Programming Tanpa Prioritas Tujuan}

Hasil kombinasi variabel keputusan dari hasil optimisasi yang dilakukan dengan LINGO dapat dilihat pada Tabel 7. Dari output yang didapat, model menyarankan untuk memproduksi produk $X_{1}$ sebanyak 31586 unit, $X_{2}$ sebanyak 31839 unit, $X_{3}$ sebanyak 31839 unit, $X_{4}$ sebanyak 60645 unit, $X_{5}$ sebanyak 16425 unit, $X_{6}$ sebanyak 16425 unit.

Secara keseluruhan, dari tabel di atas didapatkan kombinasi solusi yang optimal yaitu:

1. Sasaran memenuhi permintaan produksi terpenuhi oleh semua produk.

2. Sasaran memaksimalkan pendapatan diperoleh dengan pendapatan sebesar Rp 426.034.500,00.

3. Sasaran meminimalkan biaya produksi diperoleh biaya produksi yangharus dikeluarkan sebesar $\mathrm{Rp}$ $147.021 .000,00$.

Sasaran memaksimalkan jam kerja reguler terpenuhi karena tidak terdapat nilai penyimpangan negatif dari penggunaan jam kerja reguler $d_{9}^{-}$. 
Tabel 7 Nilai Variabel Keputusan Optimal Goal Programming Tanpa Prioritas Tujuan Berdasarkan Perhitungan LINGO.

\begin{tabular}{llcccc}
\hline No Kendala & Sasaran & Variabel & Hasil & Keterangan \\
\hline & & 31586 & X1 & 31586 & Tercapai \\
& & 31839 & X2 & 31839 & Tercapai \\
1 & Memenuhi Jumlah Permintaan Produksi & 31839 & X3 & 31839 & Tercapai \\
& & 60645 & X4 & 60645 & Tercapai \\
& & 16425 & X5 & 16425 & Tercapai \\
2 & Memaksimalkan Pendapatan & 16425 & X6 & 16425 & Tercapai \\
3 & Meminimalkan Biaya Produksi & & F1 & 426034500 & Tercapai \\
4 & Memaksimalkan Jam Kerja & 604800 & D2 & 147021000 & Tercapai \\
\hline
\end{tabular}

\section{Analisis Sensitivitas Model Goal Programming Tanpa Prioritas Tujuan}

Analisis sensitivitas merupakan analisis yang dilakukan pada hasil optimisasi. Penggunaan analisis sensitivitas bertujuan untuk mengetahui sejauh mana perubahan yang diperbolehkan pada hasil optimisasi yang telah diperoleh. Ouput LINGO menunjukkan bahwa sasaran pemenuhan target produksi untuk muffin pisang, greenis, bolu rol, brownies, coklat bakery dan pizza bakery dapat ditingkatkan sebanyak-banyaknya atau tidak terhingga. Batas yang dapat dikurangi untuk produksi muffin pisang sebanyak 31586 unit, greenis dan bolu rol sebanyak 31839 unit, brownies sebanyak 60645 unit, serta coklat bakery dan pizza bakery sebanyak 16425 unit.

Pendapatan optimal yang mungkin dapat diperoleh oleh perusahaan sebanyak Rp 426.034.500,00, dan minimal nol (0). Biaya produksi yang dapat dikeluarkan oleh perusahaan optimal dapat mencapai Rp 147.021.000,00, dan minimal nol (0). Dari hasil tersebut juga diperoleh total jam seluruh mesin bekerja masih dapat dinaikkan dan diturunkan sebesar 4582 jam 30 menit.

\section{Penyelesaian Optimal Goal Programming Dengan Prioritas Tujuan}

Hasil kombinasi variabel keputusan dari hasil optimisasi yang dilakukan dengan LINGO dapat dilihat pada Tabel 8. Dari output yang didapat, model menyarankan untuk memproduksi produk $X_{1}$ sebanyak 31586 unit, $X_{2}$ sebanyak 31839 unit, $X_{3}$ sebanyak 31839 unit, $X_{4}$ sebanyak 60645 unit, $X_{5}$ sebanyak 16425 unit, $X_{6}$ sebanyak 16425 unit.

Secara keseluruhan, dari tabel di atas didapatkan kombinasi solusi yang optimal yaitu:

1. Sasaran memenuhi permintaan produksi terpenuhi oleh semua produk.

2. Sasaran memaksimalkan pendapatan diperoleh dengan pendapatan sebesar Rp.376.759.500,00.

3. Sasaran meminimalkan biaya produksi diperoleh biaya produksi yang harus dikeluarkan sebesar Rp. 131.006.600,00.

4. Sasaran memaksimalkan jam kerja reguler terpenuhi karena tidak terdapat nilai penyimpangan negatif dari penggunaan jam kerja reguler $d_{9}^{-}$.

\section{Analisis Sensitivitas Model Goal Programming Dengan Prioritas Tujuan}

Sama seperti pada model goal programming tanpa prioritas, ouput LINGO menunjukkan bahwa sasaran pemenuhan target produksi untuk muffin pisang, greenis, bolu rol, brownies, coklat bakery dan pizza bakery dapat ditingkatkan sebanyak-banyaknya atau tidak terhingga. Batas yang dapat dikurangi untuk produksi muffin pisang sebanyak 31586 unit, greenis dan bolu rol sebanyak 31839 unit, brownies sebanyak 60645 unit, serta coklat bakery dan pizza bakery sebanyak 16425 unit.

Pendapatan optimal yang mungkin dapat diperoleh oleh perusahaan sebanyak Rp. 376.759.500,00, dan minimal nol (0). Biaya produksi yang dapat dikeluarkan oleh perusahaan optimal dapat mencapai Rp 131.006.600,00, dan minimal nol (0). Dari hasil tersebut juga diperoleh total jam seluruh mesin bekerja masih dapat dinaikkandan diturunkan sebesar 4582 jam 30 menit. 


\section{Kesimpulan dan Saran}

Dari penggunaan kedua model di atas, untuk model goal programming tanpa prioritas tujuan dan model goal programmming dengan prioritas tujuan sama-sama menghasilkan produksi yang mampu memenuhi permintaan konsumen, yaitu jumlah produksi masing-masing produk, muffin pisang sebanyak 31586 unit, greenis sebanyak 31839 unit, bolu rol sebanyak 31839 unit, brownies sebanyak 60645 unit, coklat bakery sebanyak 16425 unit dan pizza bakery sebanyak 16425 unit. Jam kerja mesin produksi dari hasil kedua model tersebut pun sudah maksimal.

Tabel 8 Nilai Variabel Keputusan Optimal Goal Programming Dengan Prioritas Tujuan Berdasarkan Perhitungan LINGO.

\begin{tabular}{llcccc}
\hline No & Kendala & Sasaran & Variabel & Hasil & Keterangan \\
\hline & & 31586 & X1 & 31586 & Tercapai \\
& & 31839 & X2 & 31839 & Tercapai \\
1 & Memenuhi Jumlah Permintaan Produksi & 31839 & X3 & 31839 & Tercapai \\
& & 60645 & X4 & 60645 & Tercapai \\
& & 16425 & X5 & 16425 & Tercapai \\
2 & Memaksimalkan Pendapatan & 16425 & X6 & 16425 & Tercapai \\
3 & Meminimalkan Biaya Produksi & & F1 & 376759500 & Tercapai \\
4 & Memaksimalkan Jam Kerja & \multirow{2}{*}{604800} & D2 & 131006600 & Tercapai \\
\hline
\end{tabular}

Terdapat perbedaan dalam pendapatan maksimum perusahaan yaitu dengan model goal programming tanpa prioritas tujuan mencapai $\mathrm{Rp} 426.034 .500,00$ dan biaya produksi minimal yang harus dikeluarkan perusahaan mencapai Rp 147.021.000,00. Sedangkan model goal programming dengan prioritas tujuan menghasilkan pendapatan maksimum mencapai Rp 376.759.500,00 dan biaya produksi minimal yang harus dikeluarkan perusahaan mencapai Rp 131.006.600,00.

Dari hasil kedua model tersebut, jika kita asumsikan bahwa keuntungan dapatdiperoleh dari pengurangan antara pendapatan dan biaya produksi, maka hasil dari model goal programming tanpa prioritas tujuan lebih optimum daripada model goal programming dengan prioritas tujuan karena menghasilkan hasil yang lebih besar. Adapain saran-saran adalah sebagai berikut.

1. Pada penelitian ini terdapat enam kriteria yang menjadi tujuan perusahaan, penelitian selanjutnya dapat menambah kriteria lain dalam pengambilan keputusan karena dalam perusahaan pasti memiliki banyak tujuan yang ingin dicapai.

2. Penelitian ini baru menggunakan model goal programming, untuk penelitian selanjutnya dapat dibandingkan dengan model lain untuk mendapatkan hasil yang lebih optimal, salah satunya adalah model de novo programming.

\section{Referensi}

[1] Ayundyah Kesumawati. 2015. Analisis Sensitivitas. Universitas Islam Indonesia. Yogyakarta.

[2] Hassan, Nasruddin dkk. 2013. A Goal Programming Model for Bakery Production. Selangor DE. School of Mathematical Sciences, Faculty of Science and Technology, University Kebangsaan Malaysia. Journal Advances in Environmental Biology, 7(1): 187-190, 2013 ISSN 1995-0756.

[3] Handoko, T.H., Pangestu Subagyo. 1995. Dasar-Dasar Operation Research. Edisi 2. Yogyakarta: BPFE-UGM.

[4] Muchlison Anis, dkk. 2007. Optimasi Perenanaan Produksi dengan Metode Goal Programming. Surakarta. Universitas Muhammadiyah Surakarta. Jurnal IImiah Teknik Industri Vol. 5 No. 3 April 2007, hal 133-143.

[5] Rad, Mansoureh Farzam, Shirouyehzad, Hadi. 2014. 1-13. Proposing an Aggregate Production Planning Model by Goal Programming Approach, a Case Study. Isfahan. Department of Industrial Engineering, Najafabad Branch, Islamic Azad University. Journal of Data Envelopment Analysis and Decision Science, ISPAC (Internasional Scientific Publications and Consulting Services)

[6] Siswanto. 2007. Operation Research. Erlangga: Jakarta.

[7] Tim Perpustakaan UPI. 2010. Modul Forecasting. Universitas Pendidikan Indonesia. Bandung. 